\title{
Türkiye Bina Deprem Yönetmeliğine (2018) Göre Sıvılaşma Potansiyeli Analizi ve Sığacık (Seferihisar/İzmir) Örneği
}

\author{
Seda Durukan ${ }^{1, *}$, Ezgi Akbuğa ${ }^{2} \mathbb{1}$ \\ ${ }^{1}$ Manisa Celal Bayar Üniversitesi, Manisa Teknik Bilimler MYO, Inşaat Bölümü, 45140, Manisa. \\ ${ }^{2}$ Manisa Celal Bayar Üniversitesi, Fen Bilimleri Enstitüsü, Inşaat Mühendisliği Anabilim Dalı, 45140, Manisa.
}

\section{Özet}

Bu çalışma, Siğacık sinırları içinde yer alan alüvyon özellikteki zeminlerin deprem etkisi altında sıvılașma potansiyelinin Türkiye Bina Deprem Yönetmeliği (TBDY)'ne göre analiz edilerek incelenmesini içermektedir. Çalı̧̧ma alanının altından Batı Anadolu Fay Hattı kollarından Seferihisar Yelki fay zonu geçmektedir. Bu riskin değerlendirilmesi amacıyla Seferihisar ilçesinin yeraltı su seviyesi yüksek olan Siğacık mahallesindeki Seferihisar Belediyesi tarafindan ruhsatlandırılmıs yapılardan elde edilen zemin etüt raporları incelenmiş, 18 adet sondaj çalışmasına ait veriler kullanılmıştır. Bu kapsamda, önce yönetmelikte verilmiş olan sıvılaşma riski analiz yöntemi tanıtılmış ve örnek bir çözüm ayrıntıları ile sunulmuştur. Ardından, Siğacık mahallesindeki veriler değerlendirilmiş ve farkl deprem senaryolar için slvilaşma riskleri hesaplanı, harita üzerinde sunulmuş ve tahmini oturma miktarları da hesaplanmıştır. Sonuç olarak, inceleme sahası içinde 1. senaryo için hesap yapılan noktaların \%65'i sıvılaşma için riskli olarak nitelendirilmiştir. 2. senaryoda sıvlaşma riski azalmış ve \%47'ye kadar inmiştir. 3. senaryoda ise, ilgili bölge \%71 oranında güvenli olarak belirlenmiştir. Bununla beraber, 1. senaryo için aynı zamanda tahmini oturma miktarları da iki yöntem kullanılarak hesaplanmış ve parsel bazında olası oturmaların her iki yöntemde de $50 \mathrm{~cm}$ 'yi aştı̆̆ sonucuna ulaşılmıştır. Derinlik boyunca her tabaka için, veri bulunmayan yerlerde ise tabaka başına hesap yapılmış ve 8,1-27,9 cm arasında değişen oturma miktarları hesaplanmıştır.

\section{$\underline{\text { Anahtar Sözcükler }}$}

Doğal Afetler, Deprem, Sıvılaşma, TBDY 2018

\section{Liquefaction Analysis According to Turkish Building Earthquake Regulation (2018) and Sığacık (Seferihisar/İzmir) Case Study}

\begin{abstract}
This study includes the investigation of the liquefaction potential of Seferihisar (Izmir) district alluvial soil deposits under possible earthquakes according to Turkey Building Earthquake Regulation (TBER). Seferihisar Yelki fault zone which is one of the branches of the Western Anatolian Fault Line lies under the study area. In order to evaluate this risk, soil survey reports belonging to the buildings licensed by Seferihisar Municipality in Siğactk district which were located by seaside and had possibly high ground water levels, were obtained and investigated, finally 18 drilling data were selected. In this context, initially the liquefaction risk analysis method given in TBER 2018 was briefly introduced and a sample solution was presented in detail. Afterwards, liquefaction risks for different earthquake scenarios were evaluated according to TBER 2018 and presented on the map and possible post-liquefaction settlements were also calculated. In the first scenario, $65 \%$ of points were found to have liquefaction susceptibility while that was $47 \%$ for the second scenario. In the third scenario, the related area was found to be $71 \%$ safe. In addition, possible post-liquefaction settlements were also calculated with two different methods for the first scenario. Finally, the settlements were found to exceed $50 \mathrm{~cm}$ for both methods. Calculations were done for each layer throughout the depth and for each layer where is data not available and settlements were found to vary between 8.1 and $27.9 \mathrm{~cm}$.
\end{abstract}

$\underline{\text { Keywords }}$

Natural Disasters, Earthquake, Liquefaction, TBER 2018

\section{Giriş}

Depremlerin yapılara etkilerinin azaltılması amaçlı yapılan çalışmaların başlangıç aşamasını oluşturan mikrobölgeleme, yer hareketi karakteristiklerinin belirlenmesi için deprem kaynağı ve zemin şartlarının karşılıklı etkileşimini göz önüne alan disiplinler arası bir konudur. Mikrobölgeleme için Uluslararası Zemin Mekaniği ve Geoteknik Mühendisliği Derneği Geoteknik Deprem Mühendisliği Teknik Komitesi tarafından hazırlanan el kitabı (ISSMGE/TC4 1999), bölgesel yer hareketi davranışı, şev stabilitesi ve sıvılaşma olmak üzere üç tip geoteknik olayın değerlendirilmesi için kabul edilmiş yaklaşımları içermektedir. 
Sıvılaşma, suya doygun gevşek zeminlerin sismik yükler altında sıkışma eğilimi ile artan boşluk suyu basıncına bağlı olarak kayma direncinin azalması veya kaybolması ile gerçekleşmektedir. Bu durum sonucunda da oldukça büyük deformasyonlar, oturmalar meydana gelmektedir (Thevanayagam vd. 2001; Çetin ve Bilge 2010; Isobe vd. 2014; Bray ve Macedo 2017; Karakan vd. 2019). Sıvılaşma üzerine gerçekleștirilen çalışmalar başlarda temiz kumlar üzerine yoğunlaşsa da zamanla, gerçekleşen depremler sonucunda edinilen tecrübeler doğrultusunda silt ve kil içeren zeminlerde de sivilaşma olduğu belirlenmiștir (Cetin vd. 2004; Hyde vd. 2006; Çetin ve Bilge 2010; Huang ve Yu 2013; Takch vd. 2016). Bununla beraber, suya doygun olmayan zeminlerin sıvılaşma potansiyeli üzerine de çalışmalar mevcuttur (Yoshimi vd. 1989; Mele ve Flora 2019; Mele vd. 2019).

Sıvılaşma potansiyelinin belirlenmesi hususunda günümüzde en çok kabul gören bağıntı, temelini Seed ve Idriss'in 1971 y1lında basitleştirilmiş sıvılaşma potansiyeli yöntemi ile oluşturduğu ve bir çalışma gurubu (Youd vd. 2001) tarafından önerilen bağıntılar olmuştur. Ülkemizde de 18 Mart 2018 tarihinde Resmi Gazete'de yayımlanan ve Ocak 2019 itibari ile de yürürlüğe girmiş olan Türkiye Bina Deprem Yönetmeliği’nde (TBDY 2018) sıvılaşma risk analizi yöntemi tanımlanmış ve ayrıntıları ile sunulmuştur. Bu çalşşmada da ilgili yönetmelikte belirtilen sıvılaşma hesabı tanıtılıp, sismik riski ve yeraltı su seviyesi yüksek olan Sığacık mahallesinde mikrobölgeleme çalışmalarına kaynak olacak şekilde bazı bölgelerde sıvılaşma analizi yapılması ve buna bağlı oturma miktarlarının tahmini amaçlanmıştır.

Literatürde, zeminin sıvılaşma potansiyelinin belirlenmesinde kullanılan pek çok arazi ve laboratuvar deneyleri vardır. Laboratuvarda kullanılan yöntem dinamik üç eksenli basınç deneyidir. Bu yöntem hem çok uzun sürmekte hem de numune alımında örselenmemiş numune alma işlemi sırasında birçok sorun çıkabilmesinden dolayı pratik uygulamalar söz konusu olduğunda pek tercih edilmemektedir. Bu sebeple araştırmacılar genel olarak arazi deneylerinden faydalanmayı tercih ederler. Arazide uygulanan deneyler içerisinde;

- Standart Penetrasyon Deneyi (SPT),

- Koni Penetrasyon Deneyi (CPT),

- Beker Penetrasyon Deneyi (BPT),

- Kayma Dalgası hızı (Vs) belirleme

yöntemlerine bağlı analizler yer almaktadır. Bu yöntemler içerisinde ise en fazla Konik Penetrasyon Deneyi (CPT) ile Standart Penetrasyon Deneyi (SPT) tercih edilen deneylerdir. Bu çalışmada ise TBDY 2018'in öngördüğü şekilde SPT verilerine göre sıvılaşma analizi gerçekleş̧irilmiş̧ir.

Çalışma kapsamında, Seferihisar Belediyesi ile yapılan bir protokol doğrultusunda Sığacık Mahallesi’nde ruhsatlandırılmış projelere ait sondaj ve arazi deney verileri elde edilmiş olup, bu veriler 1şı̆ı̆ında TBDY 2018'de belirtilen sıvılaşma analizi yöntemine göre bölgede gerçekleşebilecek farklı deprem senaryoları üzerinden değerlendirmeler yapılıp sıvılaşma için güvenlik faktörleri hesaplanmış ve harita üzerinde de gösterilmiştir. Bununla beraber, büyüklüğü $\mathrm{M}_{\mathrm{w}}=7,5$ deprem düzeyi (DD) de DD2 olan ilk deprem senaryosu için tahmini oturma miktarları da belirlenmiştir.

\section{1. İnceleme Sahası ve Jeolojisi}

Seferihisar bölgesi, İzmir ilinde deniz kıyısında konumlanmış olup bölge jeolojisinin temelini Paleozoyik ve Mesozoyik yaşlı kırıntılı ve karbonatlı kayaçlar oluşturmaktadır. Neojen ise bölgede volkanik ve sedimenter kaya türleri ile temsil edilmektedir. Maden Tetkik ve Arama Genel Müdürlüğünün İzmir Seferihisar (URLA L17-C1) Yöresinin Jeolojisi isimli raporuna göre (Yılmazer 1979) yörede İzmir Fliş Formasyonu en fazla yayılımı gösterirken çalışma alanının batısında Neojen kuzey güney doğrultusunda uzanmaktadır. Meta-kumtaşı, killişist, meta-konglomeratik kumtaşı, serizit şist ve radyolaritlerden kurulu olan İzmir Fliş Formasyonu'nun batı sınırı çalışma alanında sınırlanmaktadır. Önceki çalışmalarda Üst Kretase yaşı verilen İzmir Fliş Formasyonu'nun üzerine Neojen (Miyosen) diskordan olarak gelir. Ancak, iki formasyon arasındaki dokanak bazı yerlerde faylıdır. Çalışma alanında alüvyonun yayılımı oldukça geniştir ve kuvaterner alüvyonlardan ibarettir. Seferihisar-Sığacık Mahallesi arası, kuzey batıdaki Azmak Ovası büyük alüvyon ovalarını oluşturmaktadır. Alüvyon, alüvyon yelpazesi, yamaç molozlarından oluşan Kuvaterner yaşlı taşınmış materyaller üzerinde Aluvyal ve Koluvyal zeminler görülmektedir.

Araştırmanın yapıldığı Seferihisar ilçesine bağlı Sığacık Mahallesi aktif fay hattının üstünde yer almaktadır. Bu fay hattı İzmir'in güneybatısında Güzelbahçe ile Seferihisar ilçesindeki Sığacık körfezi arasında yer alır. Su altında devam eden çalışmalar kapsamında elde edilen verilere dayanarak fay hattının güneye doğru devam ederek Ege Denizi tabanında ilerlediğini öne sürülmektedir (Ocakoğlu vd. 2004; Ocakoğlu vd. 2005). Önceki araştırmacılar tarafından yapılan çalışmalarda da Sığacık ile İzmir Körfezi arasında yer alan Seferihisar fayının dışında da fay hatlarının bulunduğu öne sürülmüştür. Seferihisar'dan geçen Seferihisar fayı sunulan çalışmalarda Yelki-Seferihisar fay hattına karşılık gelmektedir (İnci vd. 2003). Seferihisar bölgesinde bulunan jeotermal alanın GB-KD yönünde uzanan faylar doğrultusunda yüzeye çıtı̆ğı ve kumtaşı ile kireçtaşlarından oluşmuş olduğu belirtilmektedir. Drahor vd. (1999), yaptığı çalışmalarda pek çok jeotermal özelliği olan bölgelerde olduğu gibi Seferihisar bölgesinin de, volkanizma kökenli bölgede oluştuğunu belirtmektedir. Aynı zamanda Alpin Orojenezi esnasında oluşmuş olan pek çok fay hattı ve kırıklık içerdiğini belirtmişlerdir. Erdoğan (1990), Batı Anadolu'da yer alan, İzmir bölgesinde üç tane tektonik kuşağın bulunduğunu ve bu kuşakları batıdan doğuya doğru, Karaburun kuşağı, Ankara-İzmir hattı ve Menderes masifi kuşağı olarak belirtmiş̧ir. 
Seferihisar fayının sadece karada yer alan uzunluğu Gülbahçe ile Seferihisar arasında olup uzunluğu 23 km'dir. Fayın su altında ilerleyen bölümü ile birlikte toplam uzunluğunun 30 km'ye ulaştığı sanılmaktadır (Emre vd. 2005). İnceleme alanının jeolojik formasyonunu gösteren haritası Şekil 1'de sunulmuştur.

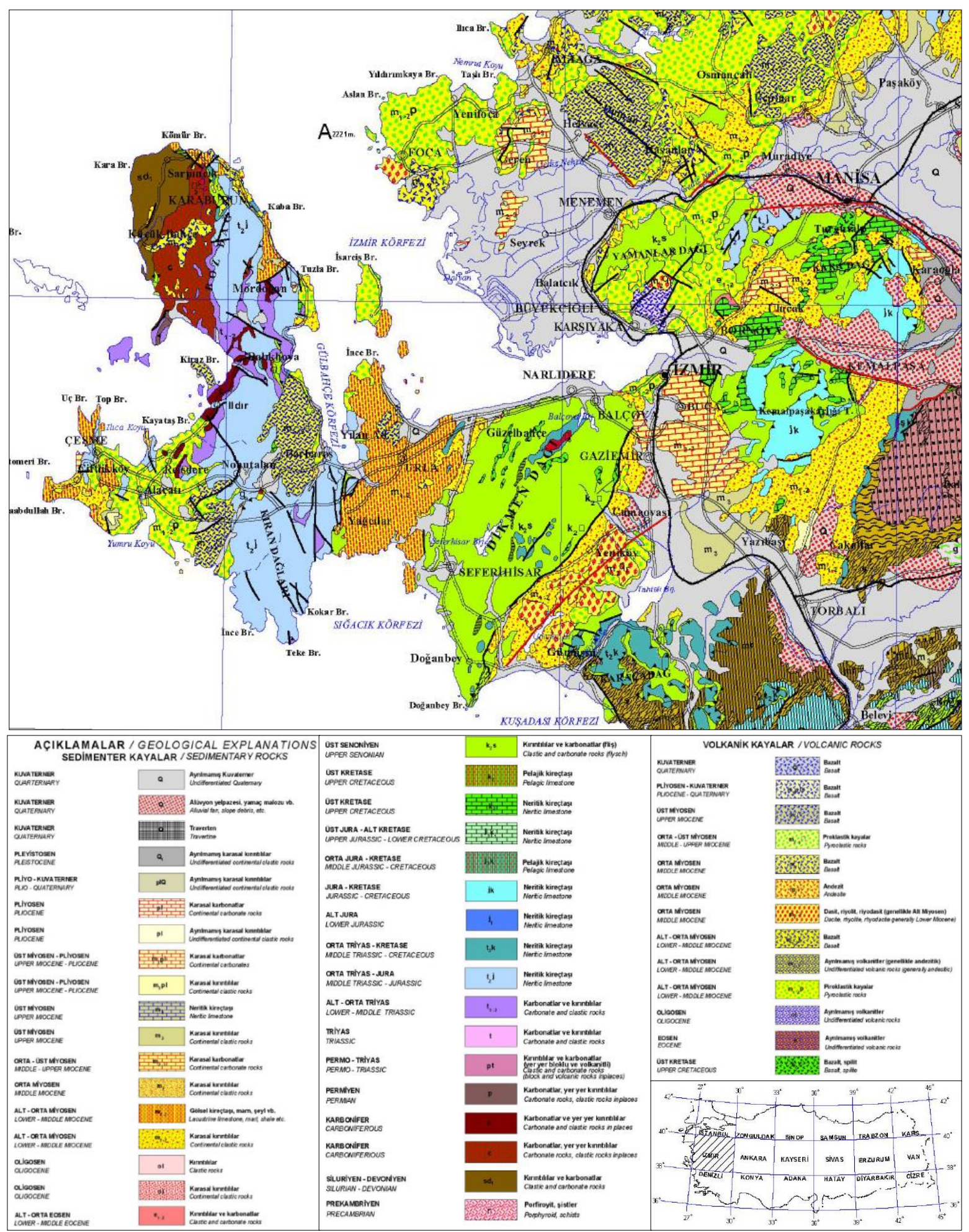

Şekil 1: İmir ve civarının jeolojik yapısını belirtir harita (MTA web sayfasından sadeleştirerek alınmıştır) (MTA 2018)

Çalışma bölgesi depremsellik açısından oldukça yoğun bir yöredir ve Batı Anadolu ve Ege'nin genel tektonik rejimi içinde değerlendirilir. Özellikle Seferihisar-Sığacık Körfezleri, Urla, Karaburun açıkları ve Sakız Adası civarı yoğun deprem etkinliği ile dikkat çekmektedir. 2005 yılı içinde Sığacık körfezinde tipik davranışı ile bir deprem dizini yaşanmış olup 2 hafta içinde en büyüğü MI= 5,9 olmak üzere 3500 deprem meydana gelmiştir (UDİM 2005). 
17 Ekim 2005 Depremlerinin olduğu bölgede genel karakteri KKD-GGB ve KB-GD gidişli eğim atım bileşeni olan doğrultu atımlı faylar mevcuttur. Fayların genel karakteri eğim atım bileşenlerinin olmasıdır.

\section{Materyal ve Metot}

Çalışma kapsamında Seferihisar Belediyesi arşivinden alınan zemin etüdü raporlarından sıvılaşma analizi için gerekli olan veriler elde edilmeye çalışılmıştır (Akbuğa 2019). Elde edilen verilerin bir kısmı örnek olarak Tablo 1'de gösterilmiştir. Sondajların yapıldığı mevkilerin harita üzerinde gösterimi ise Şekil 2'de verilmiştir. Raporlardaki SPT $\mathrm{N}_{30}$, ince dane oranı (FC) ve plastisite indisi (PI) verilerine ait istatistiki bilgiler de Tablo 2'de sunulmuştur.

Tablo 1: Seferihisar Belediyesi'nden elde edilen rapor verileri

\begin{tabular}{|c|c|c|c|c|c|c|c|c|c|}
\hline$\vec{\Xi}$ & 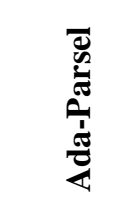 & 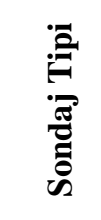 & 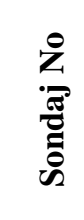 & 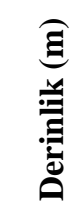 & 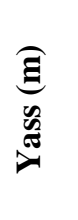 & 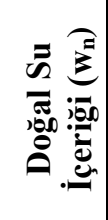 & 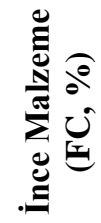 & 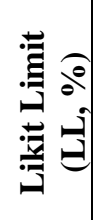 & 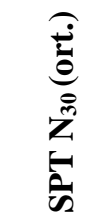 \\
\hline Siğacık & $55-10$ & SPT & SK1 & 1,95 & 3 & 20,5 & 73,18 & 32,2 & 19 \\
\hline Siğacık & $1250-3$ & SPT & SK1 & 6,45 & Yok & 21,2 & 66 & 34 & - \\
\hline Siğacık & $97-28$ & Karot & SK1 & - & Yok & - & - & - & Karot \\
\hline Sığacık & 1161-1 & SPT & SK1 & 3 & 1 & 7,1 & 2,70 & NP & 6 \\
\hline Siğacık & $1123-8$ & SPT & SK1 & 1,95 & 3 & 13,3 & 19,72 & 25,6 & 19 \\
\hline Siğacık & 3198-13 & Karot & SK1 & - & Yok & 19,9 & 54,32 & 40,3 & Karot \\
\hline Siğacık & 1163-8 & SPT & SK1 & 1,95 & 2,5 & 19,04 & 19,42 & NP & 5 \\
\hline Siğacık & $819-4$ & Karot & SK1 & - & Yok & - & - & - & Karot \\
\hline Siğacık & $1108-3$ & Karot & SK1 & - & Yok & 24,7 & 78,07 & 42,2 & 30 \\
\hline Siğacık & 1161-10 & SPT & SK1 & 1,95 & 2 & 19,8 & 17,2 & NP & 20 \\
\hline Siğacık & $91-65$ & SPT & SK1 & 1,95 & 1,5 & 21,3 & 47,8 & 45 & 11 \\
\hline Siğacık & $51-6$ & SPT & SK1 & 1,95 & 0,8 & 11,8 & 3,18 & NP & 17 \\
\hline Siğacık & $1279-1$ & SPT & SK1 & 1,95 & 1 & 12,9 & 5,27 & NP & 14 \\
\hline Sı̆̆acık & $55-1$ & SPT & SK1 & 1,95 & Yok & 17,33 & 76,52 & NP & 9 \\
\hline Siğacık & $1085-5$ & Karot & SK1 & 6 & 2 & - & - & - & Karot \\
\hline Siğacık & 1163-1 & SPT & SK1 & 15 & 1,90 & 15,8 & 37,08 & 33,8 & 7 \\
\hline Siğacık & $89-140$ & SPT & SK1 & 15 & 1,90 & 12,2 & 4,95 & NP & 2 \\
\hline Siğacık & $93-11$ & SPT & SK1 & 3,45 & 1,50 & 8,2 & 1,54 & NP & 9 \\
\hline
\end{tabular}

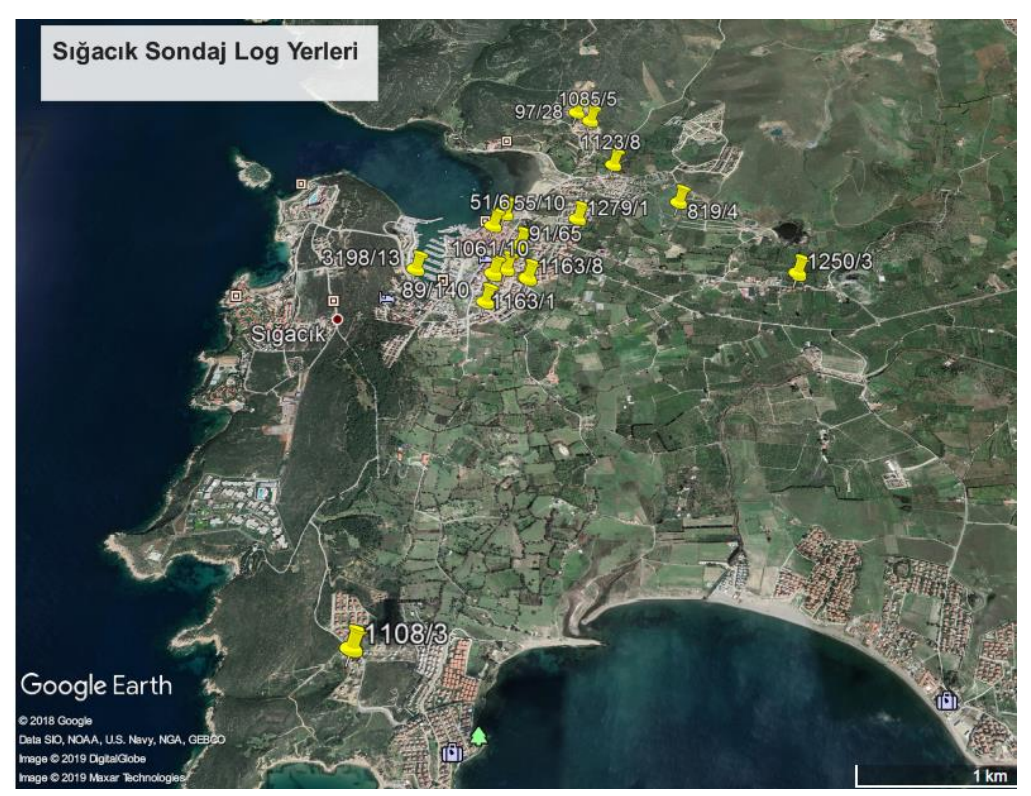

Şekil 2: Sondaj lokasyonları 
Tablo 2: Rapor verilerinin SPT N30, ince malzeme (FC) ve plastisite indisi (PI) bilgileri

\begin{tabular}{|c|c|c|c|c|c|c|c|}
\hline \multicolumn{4}{|c|}{ Ada- Parsel: 93-11 } & \multicolumn{4}{|c|}{ Ada- Parsel: 51-6 } \\
\hline & $\begin{array}{l}\text { Veri } \\
\text { Say1s1 }\end{array}$ & Ortalama & $\begin{array}{l}\text { Standart } \\
\text { sapma }\end{array}$ & & $\begin{array}{l}\text { Veri } \\
\text { Sayıs1 }\end{array}$ & Ortalama & $\begin{array}{l}\text { Standart } \\
\text { sapma }\end{array}$ \\
\hline $\mathrm{N}_{30}$ & 18 & 5,17 & 3,79 & $\mathrm{~N}_{30}$ & 14 & 16,43 & 3,55 \\
\hline $\mathrm{FC}(\%)$ & 6 & 77,22 & 37,11 & $\mathrm{FC}(\%)$ & 5 & 7,7 & 2,77 \\
\hline PI $(\%)$ & 6 & 11,67 & 5,89 & $\mathrm{PI}(\%)$ & 5 & NP & - \\
\hline \multicolumn{4}{|c|}{ Ada- Parsel: 1279-1 } & \multicolumn{4}{|c|}{ Ada- Parsel: $1123-8$} \\
\hline & $\begin{array}{l}\text { Veri } \\
\text { Say1s1 }\end{array}$ & Ortalama & $\begin{array}{l}\text { Standart } \\
\text { sapma }\end{array}$ & & $\begin{array}{l}\text { Veri } \\
\text { Say1s1 }\end{array}$ & Ortalama & $\begin{array}{l}\text { Standart } \\
\text { sapma }\end{array}$ \\
\hline $\mathrm{N}_{30}$ & 10 & 16,40 & 8,09 & $\mathrm{~N}_{30}$ & 8 & 20,13 & 4,64 \\
\hline $\mathrm{FC}(\%)$ & 4 & 29,64 & 45,60 & $\mathrm{FC}(\%)$ & 2 & 19 & 1,41 \\
\hline PI $(\%)$ & 4 & NP & - & $\mathrm{PI}(\%)$ & 2 & 11,50 & 2,12 \\
\hline \multicolumn{4}{|c|}{ Ada- Parsel: 1163-8 } & \multicolumn{4}{|c|}{ Ada- Parsel: 1163-1 } \\
\hline & $\begin{array}{l}\text { Veri } \\
\text { Say1s1 }\end{array}$ & Ortalama & $\begin{array}{l}\text { Standart } \\
\text { sapma }\end{array}$ & & $\begin{array}{l}\text { Veri } \\
\text { Say1s1 }\end{array}$ & Ortalama & $\begin{array}{l}\text { Standart } \\
\text { sapma }\end{array}$ \\
\hline $\mathrm{N}_{30}$ & 3 & 9,33 & 5,13 & $\mathrm{~N}_{30}$ & 13 & 13,08 & 13,23 \\
\hline $\mathrm{FC}(\%)$ & 3 & 64,00 & 39,23 & $\mathrm{FC}(\%)$ & 6 & 51,17 & 18,65 \\
\hline PI $(\%)$ & 3 & 22,00 & 19,08 & $\mathrm{PI}(\%)$ & 6 & 10,42 & 7,51 \\
\hline \multicolumn{4}{|c|}{ Ada- Parsel: $89-140$} & \multicolumn{4}{|c|}{ Ada- Parsel: $55-10$} \\
\hline & $\begin{array}{l}\text { Veri } \\
\text { Say1s1 }\end{array}$ & Ortalama & $\begin{array}{l}\text { Standart } \\
\text { sapma }\end{array}$ & & $\begin{array}{l}\text { Veri } \\
\text { Say1s1 }\end{array}$ & Ortalama & $\begin{array}{l}\text { Standart } \\
\text { sapma }\end{array}$ \\
\hline $\mathrm{N}_{30}$ & 10 & 5,70 & 12,14 & $\mathrm{~N}_{30}$ & 8 & 19,50 & 3,96 \\
\hline $\mathrm{FC}(\%)$ & 7 & 67,43 & 30,99 & $\mathrm{FC}(\%)$ & 2 & 61,50 & 16,26 \\
\hline PI $(\%)$ & 7 & 11,29 & 7,34 & PI $(\%)$ & 2 & 13,50 & 4,95 \\
\hline \multicolumn{4}{|c|}{ Ada- Parsel: 1161-1 } & \multicolumn{4}{|c|}{ Ada- Parsel: 1161-10 } \\
\hline & $\begin{array}{l}\text { Veri } \\
\text { Say1s1 }\end{array}$ & Ortalama & $\begin{array}{l}\text { Standart } \\
\text { sapma }\end{array}$ & & $\begin{array}{l}\text { Veri } \\
\text { Say1s1 }\end{array}$ & Ortalama & $\begin{array}{l}\text { Standart } \\
\text { sapma }\end{array}$ \\
\hline $\mathrm{N}_{30}$ & 14 & 6,36 & 2,98 & $\mathrm{~N}_{30}$ & 3 & 10,00 & 5,29 \\
\hline $\mathrm{FC}(\%)$ & 3 & 63,57 & 52,75 & $\mathrm{FC}(\%)$ & 3 & 63,78 & 52,92 \\
\hline PI $(\%)$ & 3 & 10,77 & 9,55 & $\mathrm{PI}(\%)$ & 3 & 9,33 & 9,02 \\
\hline \multicolumn{4}{|c|}{ Ada- Parsel: 91-65 } & \multicolumn{4}{|c|}{ Tüm veriler } \\
\hline & $\begin{array}{l}\text { Veri } \\
\text { Say1s1 }\end{array}$ & Ortalama & $\begin{array}{l}\text { Standart } \\
\text { sapma }\end{array}$ & & $\begin{array}{l}\text { Veri } \\
\text { Say1s1 }\end{array}$ & Ortalama & $\begin{array}{l}\text { Standart } \\
\text { sapma }\end{array}$ \\
\hline $\mathrm{N}_{30}$ & 4 & 11,00 & 0,00 & $\mathrm{~N}_{30}$ & 105 & 11,64 & 8,81 \\
\hline $\mathrm{FC}(\%)$ & 4 & 20,30 & 18,77 & $\mathrm{FC}(\%)$ & 46 & 48,22 & 37,39 \\
\hline PI $(\%)$ & 4 & 5,00 & 10,00 & PI (\%) & 46 & 8,87 & 9,09 \\
\hline
\end{tabular}

Bilindiği üzere 18 Mart 2018 tarihinde resmi gazetede yayımlanan ve 1 Ocak 2019 tarihi itibari ile yürürlüğe giren TBDY (2018)'de, Deprem Bölgelerinde Yapılacak Binalar Hakkında Yönetmeliği (DBYBHY 2007) üzerine çeşitli eklemeler yapılmasının yanı sıra kayda değer değişiklikler de yapılmıştır. $\mathrm{Bu}$ değişikliklerden bir kısmı sıvılaşma analizinde gerçekleştirilmiş ve bir yöntem tanımlanmıştır. TBDY (2018)'de sıvılaşma için özellikle bir bölüm oluşturulmuş ve dikkat edilmesi gereken hususlar belirtilmiştir. Buna göre, bir zeminde sıvılaşma analizinin uygulanması için bazı ön şartlar belirlenmiştir. Bunlar;

1. Yer altı su seviyesinin 20 m'den yüksek olması ve deprem etkisinin var olması gerekmektedir (TBDY 2018).

2. Zemin profillerinin sıvılaşabilir zemin profili tanımlamasına uyması gerekmektedir. Sıvılaşabilir zeminler kohezyonsuz veya düşük kohezyonlu $(\mathrm{PI}<\% 12)$ zeminler olarak tabir edilen siltli kum, çakıllı kum, kum, plastik olmayan silt ve silt kum karışımları olan zeminlerdir (TBDY 2018).

\subsection{TBDY 2018'e Göre Bir Sıvılaşma Analizi Örneği}

Hem bu çalışma kapsamında yapılan analizlere örnek teşkil etmesi hem de TBDY (2018)'de belirtilen sıvılaşma analizinin bir uygulama ile tanıtılması amaçlanmış ve örnek bir analiz çözümü gerçekleştirilmiştir. Analiz sırasında kullanılan datalar Seferihisar Belediyesi'nden elde edilen mevcut verilere yakın olacak şekilde seçilmiştir. Aşağıda analiz yöntemi adım adım anlatılmış ve sonuçlar sunulmuştur. Lokasyonu mevcut olmayan bu sanal örnekte, Afet ve Acil Durum Yönetimi Başkanlığı (AFAD) haritaları kullanılarak elde edilen kısa periyot tasarım spektral ivme katsayısı $\left(\mathrm{S}_{\mathrm{DS}}\right)$ bu örnek için 1 olarak kabul edilmiştir. Bu durumda, deprem tasarım sınıfını (DTS) mesken bina olarak düşündüğümüzde DTS=1 olmaktadır. SPT değerinin de 15 'ten küçük olduğu dikkate alındığında zemin sınıfı ZE grubuna girmektedir. 
Mevcut koşullara göre, TBDY (2018) madde 16.6.1'e göre sıvılaşma analizinin yapılmasının zorunlu olduğu belirtilmektedir. Örnekte deprem büyüklüğü $\mathrm{M}_{\mathrm{w}}=7,5$ deprem düzeyi (DD) de DD2 olarak alınmıştır. Zemin profili Şekil 3'te, zemine ait diğer veriler ise aşağıda Tablo 3'te sunulmuştur. Örnek analiz için yeraltı su seviyesi 2,0 m, inceleme derinliği (z) ise A noktasında ve 3,3 m. olarak alınmıştır. SPT işlemi sırasında otomatik darbeli tokmak kullanıldığ 1 kabul edilmiştir.

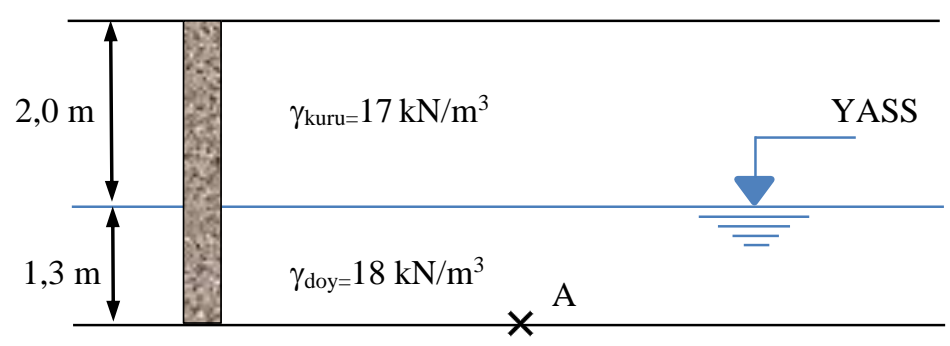

Şekil 3: Tasarı zemin profili

Tablo 3: Örnek analiz için oluşturulan tablo

\begin{tabular}{|c|c|c|c|c|c|c|}
\hline SPT-N & $\begin{array}{c}\text { Derinlik } \\
\text { (m) }\end{array}$ & $\begin{array}{l}\text { Yass } \\
(\mathbf{m})\end{array}$ & $\begin{array}{l}\text { FC } \\
(\%)\end{array}$ & $\begin{array}{c}\gamma_{\mathbf{k u r u}} \\
\left(\mathbf{k N} / \mathbf{m}^{3}\right)\end{array}$ & $\begin{array}{c}\gamma_{\text {doygun }} \\
\left(\mathbf{k N} / \mathbf{m}^{3}\right)\end{array}$ & PI \\
\hline 10 & 3,3 & 2,0 & 25 & 17 & 18 & NP \\
\hline
\end{tabular}

\subsubsection{SPT Değerlerinin Düzeltilmesi}

Analizde Türkiye'de yaygın olarak kullanılan donanım türüne göre düzeltme katsayıları belirlenmiştir. TBDY (2018) tarafından otomatik darbeli tokmak için önerilen düzeltme faktörleri seçilmiştir, buna göre;

- $\mathrm{C}_{\mathrm{E}}$ (enerji oranı düzeltme katsayısı) $=0,90$

- $\mathrm{C}_{\mathrm{B}}$ (sondaj kuyusu çapi) $=1$

- $\mathrm{C}_{\mathrm{R}}$ (tij boyu) $=0,75$

- $\mathrm{C}_{\mathrm{S}}$ (numune alıcı düzeltme katsayısı) $=1$

- $\mathrm{C}_{\mathrm{N}}($ derinlik düzeltme katsayıs1 $)=\sqrt{95,76 * \frac{1}{\sigma^{\prime}{ }_{\mathrm{v}}}} \leq 1,7$

$\mathrm{C}_{\mathrm{N}}$ hesabını yapabilmek için öncelikle efektif gerilmenin hesaplanması gerekmektedir. Efektif gerilme formülü Denklem 1'de gösterilmektedir. Denklemde yer alan ifadeler aşağıdaki gibi hesaplanır.

$$
\begin{aligned}
& \sigma^{\prime}=\sigma-\mathrm{u} \\
& \\
& \sigma=17 * 2+18^{*} 1,3=57,4 \mathrm{kN} / \mathrm{m}^{2} \\
& \mathrm{u}=1,3 * 9,81=12,75 \mathrm{kN} / \mathrm{m}^{2} \\
& \sigma^{\prime}=44,65 \mathrm{kN} / \mathrm{m}^{2} \\
& \mathrm{C}_{\mathrm{N}}=1,46
\end{aligned}
$$

Tüm düzeltme katsayılarının elde edilmesinin ardından araziden elde edilmiş olan SPT-N değeri düzeltme katsayıları ile çarpılarak $\left(\mathrm{N}_{1}\right)_{60}$ ifadesine düzeltilecektir. $\left(\mathrm{N}_{1}\right)_{60}$ '1n hesab1 için Denklem 2'de verilmiş olan formül kullanilacaktır.

$$
\begin{aligned}
& \left(\mathrm{N}_{1}\right)_{60}=\mathrm{N} * \mathrm{C}_{\mathrm{N}} * \mathrm{C}_{\mathrm{S}} * \mathrm{C}_{\mathrm{B}} * \mathrm{C}_{\mathrm{R}} * \mathrm{C}_{\mathrm{E}} \\
& \left(\mathrm{N}_{1}\right)_{60}=10 * 1,46 * 1 * 1 * 0,75 * 0,90=9,9
\end{aligned}
$$

$\mathrm{Bu}$ aşamada SPT verilerinin ince dane oranına (FC) göre düzeltilme uygulanması gerekmektedir. İnce dane oranına göre düzeltilen darbe sayısı olan $\left(\mathrm{N}_{1}\right)_{60, \mathrm{f}}$ için TBDY (2018)'de tanımlanmış olan formülasyon Denklem 3 'te verilmiştir. Buna göre önce sırası ile $\alpha$ ve $\beta$ değerleri hesaplanacaktır. Bu örnekteki ince dane oranı \%25 olarak tanımlandığı için $\alpha$ ve $\beta$ değerleri için Denklem 4 ve 5 'teki formüller ( $\% 5 \leq \mathrm{FC} \leq \% 35$ için) uygulanmıştır.

$\left(\mathrm{N}_{1}\right)_{60, \mathrm{f}}=\alpha+\beta *\left(\mathrm{~N}_{1}\right)_{60}$ 
$\% 5 \leq \mathrm{FC} \leq \% 35$ için;

$\alpha=\exp \left[1,76-\left(190 / \mathrm{FC}^{2}\right)\right]$

$\beta=0,99+\left(\mathrm{FC}^{1,5} / 1000\right)$

Sonuç olarak; $\alpha=4,289$ ve $\beta=1,115$ değerlerine ulaşılmıştır. Denklem 3'e göre $\left(\mathrm{N}_{1}\right)_{60, \mathrm{f}}$ ise 15,3 olarak hesaplanmıştır.

\subsubsection{Sıvılaşma Direncinin $\left(\tau_{R}\right)$ Hesaplanması}

Sıvılaşma direnci olan $\tau_{R}$, moment büyüklüğü 7,5 olan depreme karşı gelen çevrimsel dayanım oranının $\left(\mathrm{CRR}_{\mathrm{M} 7,5}\right)$, tasarım depremi moment büyüklüğü düzeltme katsayısı $\left(\mathrm{C}_{\mathrm{M}}\right)$ ve efektif düşey gerilme $\left(\sigma^{\prime}{ }_{v}\right)$ ile çarpılması sonucunda elde edilecektir (TBDY 2018). Formülasyonu Denklem 6'da verilmiştir. Denklemdeki efektif gerilme değeri için Denklem 1'den elde edilen değer kullanılacak olup, $C_{M}$ ifadesi için de Denklem 7'den yararlanılacaktır. CRR $\mathrm{R}_{\mathrm{M} 7,5}$ ifadesi için de Denklem 8 kullanılacaktır.

$\tau_{R}=C R R_{M 7,5} * C_{M} * \sigma^{\prime}{ }_{V}$

$C_{M}=\frac{10^{2,24}}{M_{W}{ }^{2,56}}$

$C R R_{7.5}=\frac{1}{34-\left(\mathrm{N}_{1)_{60, \mathrm{f}}}\right.}+\frac{\left(\mathrm{N}_{1)_{60, \mathrm{f}}}\right.}{135}+\frac{50}{\left[10 .\left(\mathrm{N}_{1)_{60, \mathrm{f}}}+45\right]^{2}\right.}-\frac{1}{200}$

Buna göre; $\tau_{\mathrm{R}}=7,28 \mathrm{kN} / \mathrm{m}^{2}$ olarak hesaplanmıştır.

\subsubsection{Zeminde Oluşan Kayma Direncinin $\left(\tau_{\text {deprem }}\right)$ Hesaplanması}

Zeminde oluşan kayma direnci formülü TBDY (2018)'de tanımlanmış olup Denklem 9'da verilmiştir.

$\tau_{\mathrm{deprem}}=0,65 * \sigma_{\mathrm{V} 0} * 0,4 * \mathrm{~S}_{\mathrm{DS}} * \mathrm{r}_{\mathrm{d}}$

Burada $\sigma_{\mathrm{V} 0}$ hesaplamanın yapıldı ̆̆ 1 derinlikteki toplam düşey gerilmeyi, $r_{d}$ derinlik faktörü olup inceleme yapılan derinlikteki (z) gerilme azaltma katsayısını, $\mathrm{S}_{\mathrm{DS}}$ ise kısa periyot tasarım spektral ivme katsayısını ifade etmektedir. Gerilme azaltma katsayısı, $r_{d}$ için gerekli formül Denklem 10'da verilmiştir. $\mathrm{S}_{\mathrm{DS}}$ İnceleme alanının koordinatları kullanılarak AFAD'ın hazırladığı deprem tehlike haritalarından elde edilen bir veridir. Bu örnekte 1 alınmıştır. Buna göre;

$\mathrm{r}_{\mathrm{d}}=1-0,00765 * z \quad z \leq 9,15 m$

Sonuç olarak da $\tau_{\text {deprem }}=14,58 \mathrm{kN} / \mathrm{m}^{2}$ elde edilmiştir. TBDY (2018)'de sıvılaşmaya karşı güvenlik koşulu (FS); $\frac{\tau_{R}}{\tau_{\text {deprem }}} \geq 1,10$ olarak tanımlanmıştır. Buna göre;

$$
F S=\frac{\tau_{R}}{\tau_{\text {deprem }}}=\frac{7,28}{14,58}=0,50 \text { elde edilmişstir. }
$$

Elde edilen FS değeri 1,1'den küçük olduğu için sıvılaşma riskinin mevcut olduğu sonucu elde edilir. Yukarıdaki hesaplama TBDY (2018)'de anlatıldığı şekli ile gerçekleştirilmiştir, bununla beraber, SPT düzeltmeleri uygulanarak elde edilen $\left(\mathrm{N}_{1}\right)_{60}$ değeri enerji verimliliğinin \%60 olduğu koşullar için geçerlidir. Oysaki, ülkemiz için geçerli olan enerji verimliliği yüzdesi \%45 olarak bilinmektedir. Dolayısı ile, enerji verimliliğindeki bu farkın hesaba yansıtılması ve Türkiye'de gerçekleştirilmiş ölçümlerin ilgili hesaptaki $\% 60$ enerji verimliliği koşuluna dönüştürülmesi gerekmektedir. Bu da, \%45 değerinin \%60 değerine oranı olan 0,75 katsayısına denk gelmektedir, diğer bir deyişle Türkiye'de elde edilen SPT değerlerinin 0,75 ile çarpılması gerekmektedir. Hesabı Türkiye'deki enerji verimliliğini dikkate alarak ilerlettiğimizde, $\left(\mathrm{N}_{1}\right)_{60}$ 'a denk gelen düzeltilmiş SPT sayısının 7,4 olacağ1 görülmektedir, bu SPT değerine göre yukarıdaki ile aynı şekilde hesaplanan sıvılaşmaya karşı güvenlik koşulu (FS) ise 0,42 olarak elde edilmektedir. Bu çalışmanın devamında belirtilen enerji verimliliği düzeltmesi tüm noktalarda uygulanmış olup TBDY (2018)'de belirtilmemiş olsa da daha güvenli tarafta kalmak için tüm hesaplarda uygulanması önemle tavsiye edilmektedir. 


\subsection{Sıvılaşma Kaynaklı Tahmini Oturma Hesabı}

$\mathrm{Bu}$ çalışmada inceleme alanı kapsamında sıvılaşmaya bağlı zemin oturmalarının tahmin edilmesi de amaçlanmıştır. Oturma hesabı için Ishihara ve Yoshimine (1992) ve Çetin vd. (2009) olmak üzere iki yöntemden yararlanılmışıtır. Ishihara ve Yoshimine (1992) yöntemi sıvılaşma kaynaklı oturmaların değerlendirilmesinde en çok bilinen ve kullanılan yöntemlerden biridir. Çetin vd. (2009) yöntemi ise Ishihara ve Yoshimine (1992) yönteminden farklı olarak tabaka derinliklerine bağlı olarak derinliğe göre etkisi azalan bir "ağırlık faktörü" kavramı içermesi ile bilinmektedir. Bahsi geçen bu faktör, yüzey tabakalarının daha erken sıvılaşması ile derinlere iletilen kayma gerilmeleri ve çevrim sayılarındaki azalma ile ilişkilendirilmektedir (Çetin vd. 2009). Her iki yöntem de sıvılaşan tabaka kalınlıklarının bir abak vasıtası ile bulunacak bir hacim birim deformasyon katsayısı $\left(\varepsilon_{\mathrm{v}}\right)$ ile çarpımı ilkesine dayanmaktadır. Bu çalışma kapsamında Ishihara ve Yoshimine (1992) ve Çetin vd. (2009)'a göre gerçekleştirilen hesaplamalar için yararlanılan abaklar sırası ile Şekil 4 ve Şekil 5’te sunulmuştur.

Ishihara ve Yoshimine (1992) yönteminde sıvılaşma analizi sonucunda elde edilen FS güvenlik faktörünün SPT N ${ }_{1}$ değerleri ile abak üzerinde çakıştırılıp hacimsel birim deformasyon değerlerine ulaşılması hedeflenmektedir. Burada $\mathrm{N}_{1}$ değeri enerji verimliliğin \%72 olduğu SPT verilerini ifade etmektedir. Ishihara ve Yoshimine (1992) yöntemindeki $\mathrm{N}_{1}$ değeri için, \%60 enerji verimliliğine göre elde edilmiş olan $\mathrm{N}_{1,60}$ değerinin, bu iki verimlilik değerinin oranı olan 0,833 ile çarpılarak bulunması önerilmektedir. Bununla beraber Çetin vd. (2009) yönteminde $\mathrm{N}_{1,60}$ ve $1 \mathrm{~atm}$ efektif gerilme altında konsolide edilip, tek boyutlu olarak 20 çevrimin uygulandığı basit kesme deneyine ait tekrarlı gerilme oranı

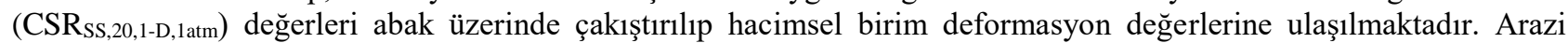
değerlerinden elde edilen tekrarlı kayma gerilme oranının ( $\mathrm{CSR}_{\text {saha }}$ ), abakta kullanılacak CSRss,20,1-D,latm eşdeğerine çevrilmesi gerekmektedir. Bu dönüşüm aşağıda Denklem 11-15’te sunulmuştur. Denklem 12'de önerilen düzeltmeler, saha koşullarındaki çok yönlü yükleme $\left(K_{m d}\right)$, farklı deprem büyüklükleri $\left(K_{M_{w}}\right)$ ve farklı düşey efektif gerilme değerlerinin $\left(K_{s}\right)$ etkilerini göz önünde bulundurmaktadır.

$$
\begin{aligned}
& \operatorname{CSR}_{\text {saha }}=0,65 \frac{\sigma_{v}^{\prime}}{\sigma_{v}^{\prime}} \frac{a_{\max }}{g} r_{d} \\
& \operatorname{CSR}_{S S, 20,1-D, 1 a t m}=\frac{C S R_{\text {saha }}}{K_{m d} K_{M w} K_{\sigma}} \\
& K_{m d}=0,361 \ln \left(D_{R}\right)-0,579 \\
& K_{M w}=\frac{87,1}{M_{w}^{2,217}} \\
& K_{\sigma}=\left(\frac{\sigma_{v}^{\prime}}{P_{a}}\right)^{f-1} \text { vef }=1-0,005 D_{R}
\end{aligned}
$$

Yukarıdaki denklemlerde; $\mathrm{CSR}_{\text {saha }}$ sahadaki tekrarlı kayma gerilme oranını, $\mathrm{a}_{\max } / \mathrm{g}$ maksimum yüzey ivmesinin yerçekimine oranını, $\sigma_{v}$ ve $\sigma_{v}^{\prime}$ sırasıyla toplam ve efektif gerilmeleri, $r_{d}$ derinlik faktörünü, $D_{R}$ rölatif sıkıllğı, $M_{w}$ deprem büyüklüğünü (magnitude), $\mathrm{P}_{\mathrm{a}}$ da atmosfer basıncını temsil etmektedir.

Şekil 5'te sunulan abaktaki $\mathrm{N}_{1,60, C S}$ ifadesi, $\mathrm{N}_{1,60}$ düzeltmelerine ilaveten TBDY (2018)'den farklı bir ince dane düzeltmesi uygulanmış SPT değerlerini ifade etmektedir bu düzeltmenin Cetin vd. (2004)'te belirtilen şekilde uygulanmas1 gerekmektedir (Denklem 16 ve 17).

$$
\begin{aligned}
& N_{1,60, c S}=N_{1,60} C_{F I N E S} \\
& C_{F I N E S}=(1+0,004 F C)+0,05\left(\frac{F C}{N_{1,60}}\right) \text { lim: } \% 5 \leq F C \leq \% 35 ; F C<5 \text { ise } F C=0 ; F C>35 \text { ise } F C=35
\end{aligned}
$$




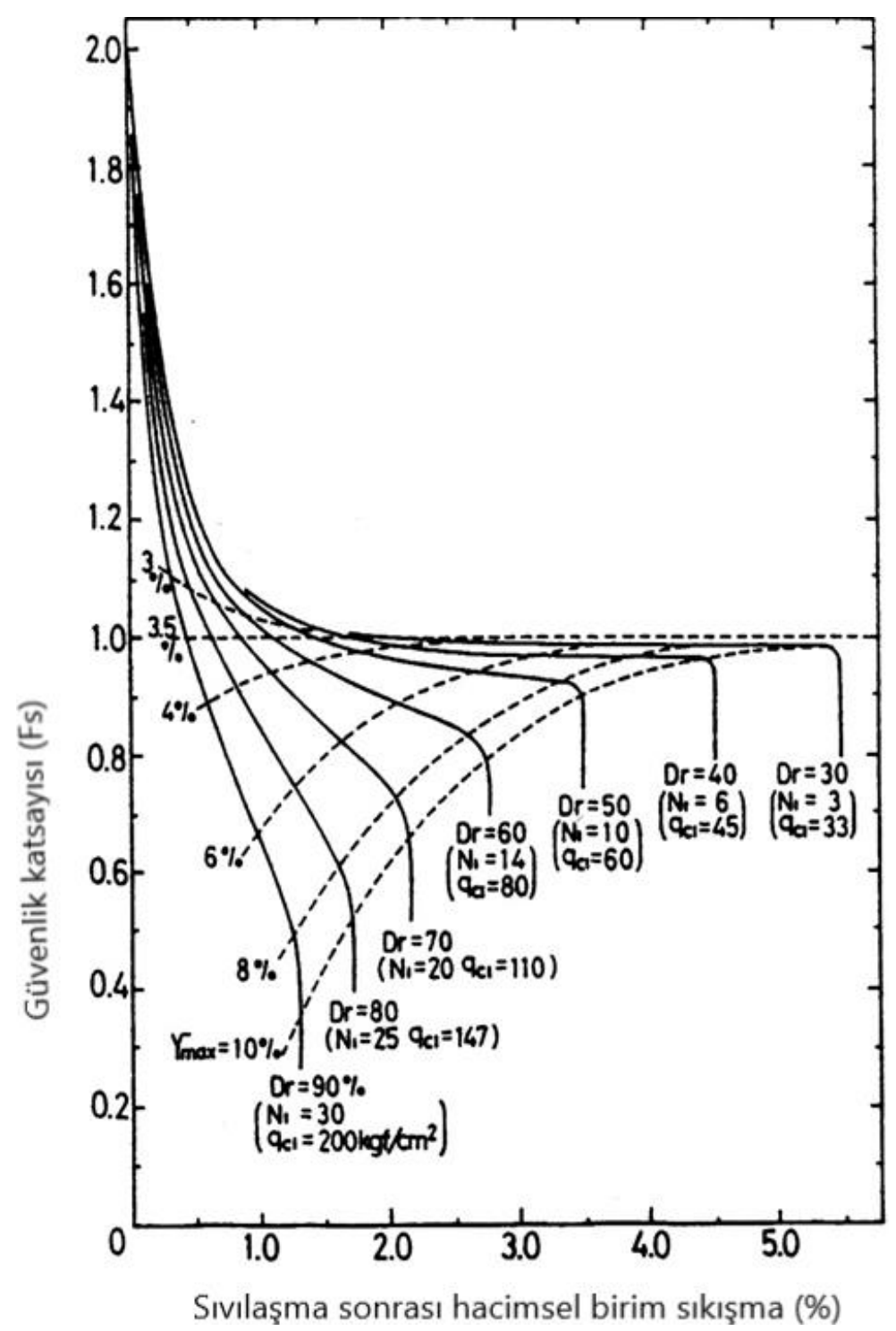

Şekil 4: Ishihara ve Yoshimine (1992) tarafından oluşturulan abak 


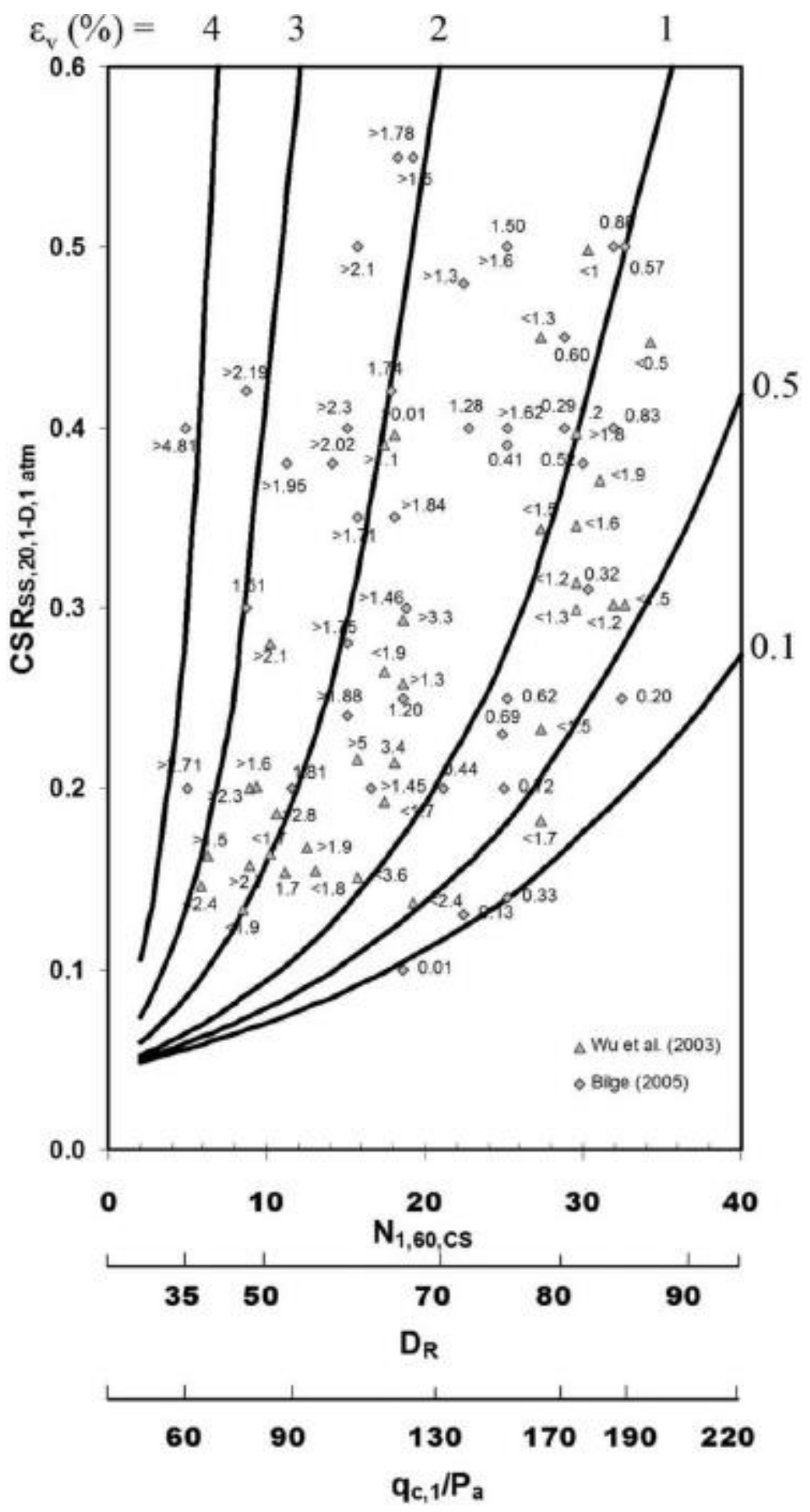

Şekil 5: Çetin vd. (2009) tarafından oluşturulan abak

\section{Bulgular}

Belediyeden elde edilen 18 adet rapordan sadece 6 tanesinde TBDY (2018)'e göre sıvılaşma hesabı için gerekli olan veriler tam olarak bulunabilmiştir. Kalan 12 raporun 6 tanesinde yeraltı suyu bulunmadığı için sıvılaşma analizi tanım itibari ile yapılmamış ve direkt olarak sıvılaşma riski bulunmamaktadır şeklinde değerlendirilmiştir. Bunlara ek olarak yeraltı su seviyesi, zemin özellikleri ve SPT değerleri gözetilerek sıvılaşma analizi yapılması gerektiği anlaşılan raporlardan bazılarında analiz için gerekli olan birim hacim ağırlık değerlerinin eksik oldukları tespit edilmiştir. Bu sebeple yeraltı suyu seviyesi tanımlı ve SPT verisi mevcut olan raporlar arasından zemin özellikleri için çevreye ve SPT değerlerine uyumlu olacak şekilde tahmini birim hacim ağırlık değerleri kullanılarak değerlendirme yapılmıştır. Buna göre Seferihisar Belediyesi'nden elde edilen raporlara göre gerçekleştirilen sıvılaşma analiz sonuçları Tablo 4'te verilmiştir. Değerlendirmelerin tümü için bir harita oluşturulmuş ve Şekil 6'da sunulmuştur. Bu haritada yeşil renkler risk bulunmayan noktaları ifade ederken, kırmızı renkler riskli noktaları ifade etmektedir. 
Tablo 4: Sıvılaşma analizi sonuç tablosu

\begin{tabular}{|c|c|c|c|c|c|c|c|c|}
\hline Semt & $\begin{array}{c}\text { Ada- } \\
\text { Parsel }\end{array}$ & $\begin{array}{c}\gamma_{\text {kuru }} \\
\left(\mathbf{k N} / \mathbf{m}^{3}\right)\end{array}$ & $\begin{array}{c}\gamma_{\text {doggun }} \\
\left(\mathbf{k N} / \mathbf{m}^{3}\right)\end{array}$ & $\begin{array}{l}\text { FC } \\
(\%)\end{array}$ & $\begin{array}{c}\text { Yass } \\
\text { (m) }\end{array}$ & $\mathbf{N}_{30}$ & $\begin{array}{l}\text { Derinlik* } \\
\text { (m) }\end{array}$ & FS \\
\hline Sığacık & $1161-1$ & 16,18 & 19,19 & 95,56 & 1 & 8 & 3 & 0,31 \\
\hline Siğacık & $51-6$ & 16,63 & 17,85 & 10,56 & 0,8 & 14 & 3 & 0,29 \\
\hline Siğacık & $1279-1$ & 16,72 & 18,63 & $\begin{array}{l}8,83 \\
\end{array}$ & 1 & 16 & 3 & 0,34 \\
\hline Siğacık & $1163-1$ & 11,36 & 16,47 & 29,64 & 2 & 5 & 3 & 0,28 \\
\hline Siğacık & $89-140$ & 16,63 & 18,68 & 4,95 & 2 & 3 & 3 & 0,15 \\
\hline Sığacık & $93-11$ & 17,08 & 18,51 & 1,54 & 1,5 & 9 & 3 & 0,22 \\
\hline Siğacık & $55-1$ & 15,70 & - & 26,63 & YOK & - & 1,95 & $>1,10$ \\
\hline Siğacık & $1250-3$ & - & - & 66 & YOK & - & 6,00 & $>1,10$ \\
\hline Sığacık & $\begin{array}{l}97-28 \\
\end{array}$ & - & - & - & YOK & $\mathrm{CR}^{\mathrm{x}}$ & - & $>1,10$ \\
\hline Siğacık & $3198-13$ & 15,73 & 18,96 & 54,32 & YOK & $\mathrm{CR}^{\mathrm{x}}$ & 1,50 & $>1,10$ \\
\hline Siğacık & $819-4$ & - & - & - & YOK & $\mathrm{CR}^{\mathrm{x}}$ & 3,00 & $>1,10$ \\
\hline Sığacık & $1108-3$ & 14,88 & 19,29 & 78,07 & YOK & 30 & 1,50 & $>1,10$ \\
\hline Siğacık & $1163-8$ & 17,46 & 19,52 & 19,42 & 2,5 & 8 & 4,5 & 0,25 \\
\hline Siğacık & $55-10$ & 16,68 & 17,76 & 50 & 3 & 22 & 4,5 & 0,66 \\
\hline Sığacık & $1123-8$ & 16,68 & 17,76 & 15 & 3 & 20 & 4,5 & 0,52 \\
\hline Siğacık & $1161-10$ & 16,18 & 19,19 & 15 & 2 & 21 & 3 & 0,58 \\
\hline Siğacık & $91-65$ & 17,07 & 18,49 & 35 & 1,5 & 11 & 3 & 0,41 \\
\hline
\end{tabular}

* Hesaplar için kullanılan veriler ilgili derinliklere göre verilen değerlerdir.

$\times$ Karot

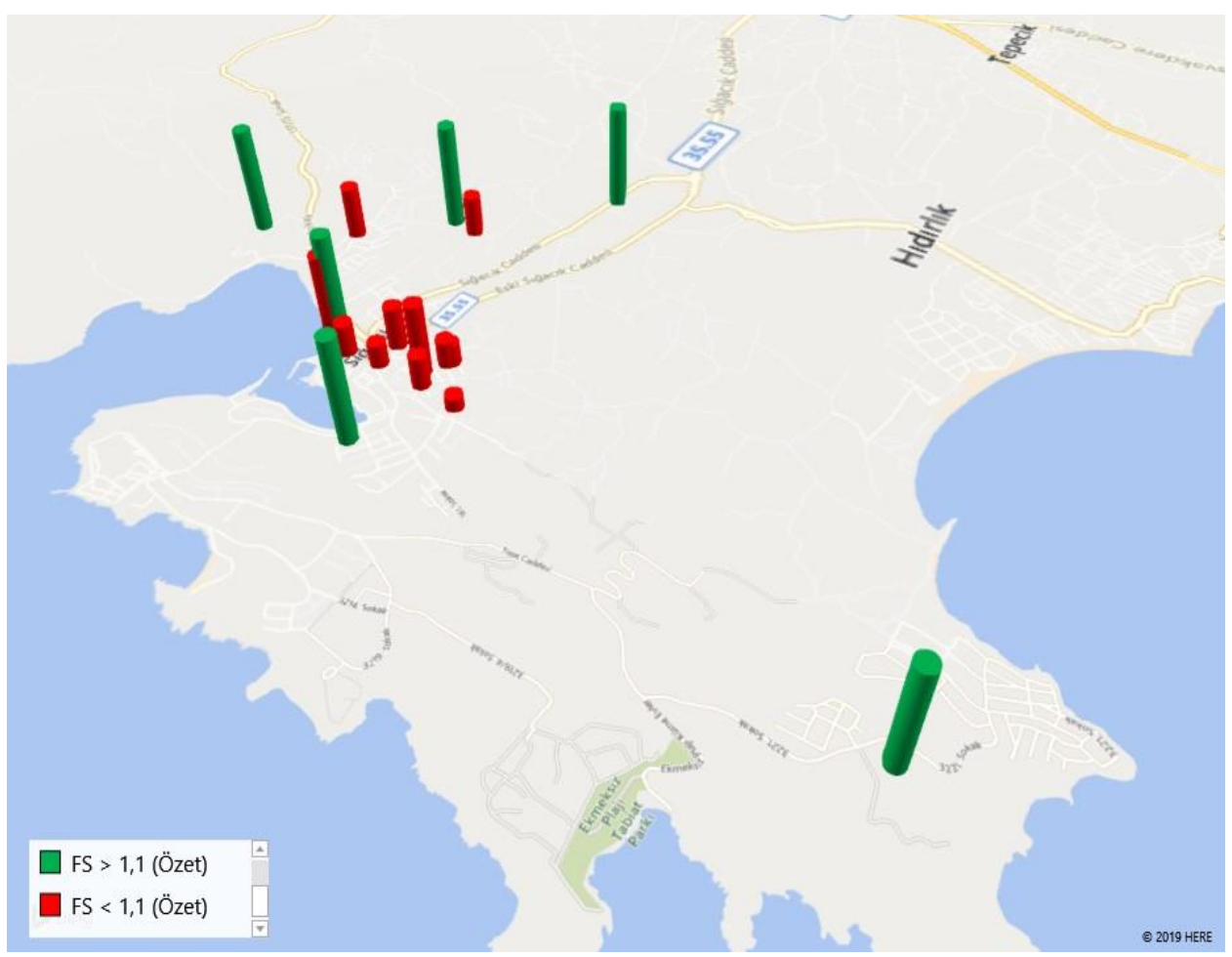

Şekil 6: Inceleme alanı kapsamındaki verilere ait haritalandırma

$\mathrm{Bu}$ çalışmada farklı büyüklükteki depremlerin etkisi altında sıvılaşma analizleri de gerçekleştirilmiştir. İnceleme alanındaki jeolojik ve jeofizik değerlendirmeler sonucunda bölgede beklenen farklı depremlere göre deprem senaryoları düşünülmüş ve sıvılaşma analizleri bu farklı deprem senaryolarına göre çeşitlendirilmiştir. Bu senaryoların ilki yukarıda sunulan DD2 deprem düzeyinde ve 7,5 büyüklüğündeki deprem olasılığı içindir (1. Senaryo). Bu hesab1 takiben, hem DD3 deprem düzeyi ve 7 büyüklüğündeki deprem (2. Senaryo) hem de DD4 deprem düzeyi ve 6,5 büyüklüğündeki deprem (3. Senaryo) için sıvılaşma analizleri gerçekleştirilmiştir. Aşağıda Tablo 5'te, elde edilen verilere göre yapılan hesaplamalarda farklı deprem senaryoları için $\mathrm{S}_{\mathrm{DS}}$ ve FS değerleri sunulmuştur. 
Tablo 5: Farklı deprem senaryolarında gerçekleştirilen sıvılaşma analizine ait kısa periyot tasarım spektral ivme katsayıları $\left(S_{D S}\right)$ ve güvenlik katsayıları $(F S)$

\begin{tabular}{|c|c|c|c|c|c|c|}
\hline \multirow{2}{*}{$\begin{array}{c}\text { ADA - } \\
\text { PARSEL }\end{array}$} & \multicolumn{2}{|c|}{$\begin{array}{c}\text { 1. Senaryo } \\
\text { DD2-Mw(7,5) }\end{array}$} & \multicolumn{2}{c|}{$\begin{array}{c}\text { 2. Senaryo } \\
\text { DD3-Mw(7) }\end{array}$} & \multicolumn{2}{c|}{$\begin{array}{c}\text { 3. Senaryo } \\
\text { DD4-Mw(6,5) }\end{array}$} \\
\cline { 2 - 7 } & SDS & FS & SDS & FS & SDS & FS \\
\hline $1161 / 1$ & 1,159 & 0,31 & 0,611 & 0,70 & 0,468 & 1,11 \\
\hline $51 / 6$ & 1,160 & 0,29 & 0,613 & 0,65 & 0,468 & 1,03 \\
\hline $1279 / 1$ & 1,160 & 0,34 & 0,613 & 0,76 & 0,468 & 1,20 \\
\hline $1163 / 1$ & 1,159 & 0,28 & 0,611 & 0,63 & 0,468 & 1,00 \\
\hline $89 / 140$ & 1,158 & 0,15 & 0,610 & 0,34 & 0,467 & 0,54 \\
\hline $93 / 11$ & 1,160 & 0,22 & 0,611 & 0,50 & 0,468 & 0,79 \\
\hline $1163 / 8$ & 1,159 & 0,25 & 0,611 & 0,51 & 0,468 & 0,81 \\
\hline $55 / 10$ & 1,160 & 0,66 & 0,613 & 1,50 & 0,468 & 2,37 \\
\hline $1123 / 8$ & 1,163 & 0,52 & 0,614 & 1,18 & 0,469 & 1,87 \\
\hline $1161 / 10$ & 1,159 & 0,58 & 0,611 & 1,32 & 0,468 & 2,08 \\
\hline $91 / 65$ & 1,160 & 0,41 & 0,611 & 0,93 & 0,468 & 1,47 \\
\hline
\end{tabular}

Yukarıdaki hesaplamalardan elde edilen sonuçlardan her bir deprem senaryosuna göre riskli bölgeler tespit edilmiş ve uydu görüntüsü üzerine işlenmiştir. Bu haritalarda yeşil renkler risksiz bölgeleri (FS $\geq 1,1)$, kırmızı renkler ise riskli bölgeleri $(\mathrm{FS}<1,1)$ ifade etmektedir. 1. Senaryoya ait harita üzerinde gösterim Şekil 7'de; 2. Senaryoya ait harita üzerinde gösterim Şekil 8'de ve son olarak 3. Senaryoya ait harita üzerinde gösterim Şekil 9'da sunulmuştur.

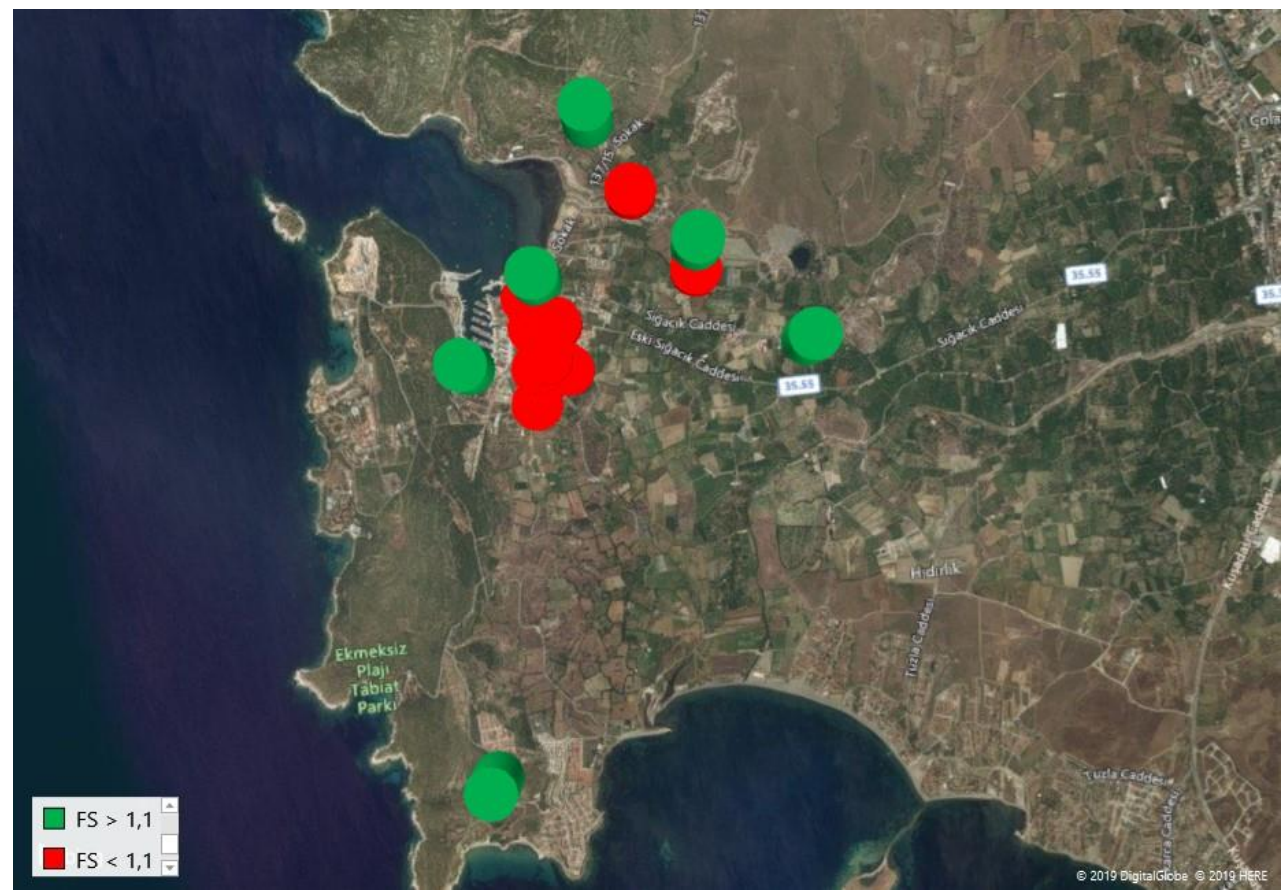

Şekil 7: Inceleme alanı verilerine ait 1. senaryoya $(D D 2$ ve $M w=7,5)$ göre sıvılaşma risk haritası

Şekil 7'de sunulan 1. Senaryoya ait sonuçlarda sıvılaşma beklenmeyen risksiz bölgeler sadece ilgili raporlarda bir yeraltı su seviyesi tanımlanmamış olan noktalardan oluşmaktadır. Bir yeraltı su seviyesi bulunmadığı için hesap yapılmamış ve doğrudan risk yoktur mertebesinde değerlendirilmiştir. Bununla beraber, hesabın gerçekleştirildiği diğer tüm bölgelerde sıvılaşma riski tespit edilmiştir. Burada unutulmaması gereken husus, veriler değerlendirilirken ilgili belediyeden elde edildiği şekilde kullanıldığıdır. Birbirine bu kadar yakın noktalardaki yeraltı su seviyelerindeki farklılıklar verilerin güvenilirliğinin sorgulanmasına neden olmaktadır. Bununla beraber, sonuç olarak çalışma bölgesindeki toplam 17 noktanın 11'inde sıvılaşma riski bulunmuş diğer 6 adedinde ise bulunmamıştır. Diğer bir deyişle, eldeki hesap noktalarının \%65'i sıvılaşma için riskli olarak nitelendirilmiştir. Yeraltı su seviyelerindeki olası yanlış değerlendirmelerin de göz önünde bulundurulması ile bu oranın artması beklenmektedir. 


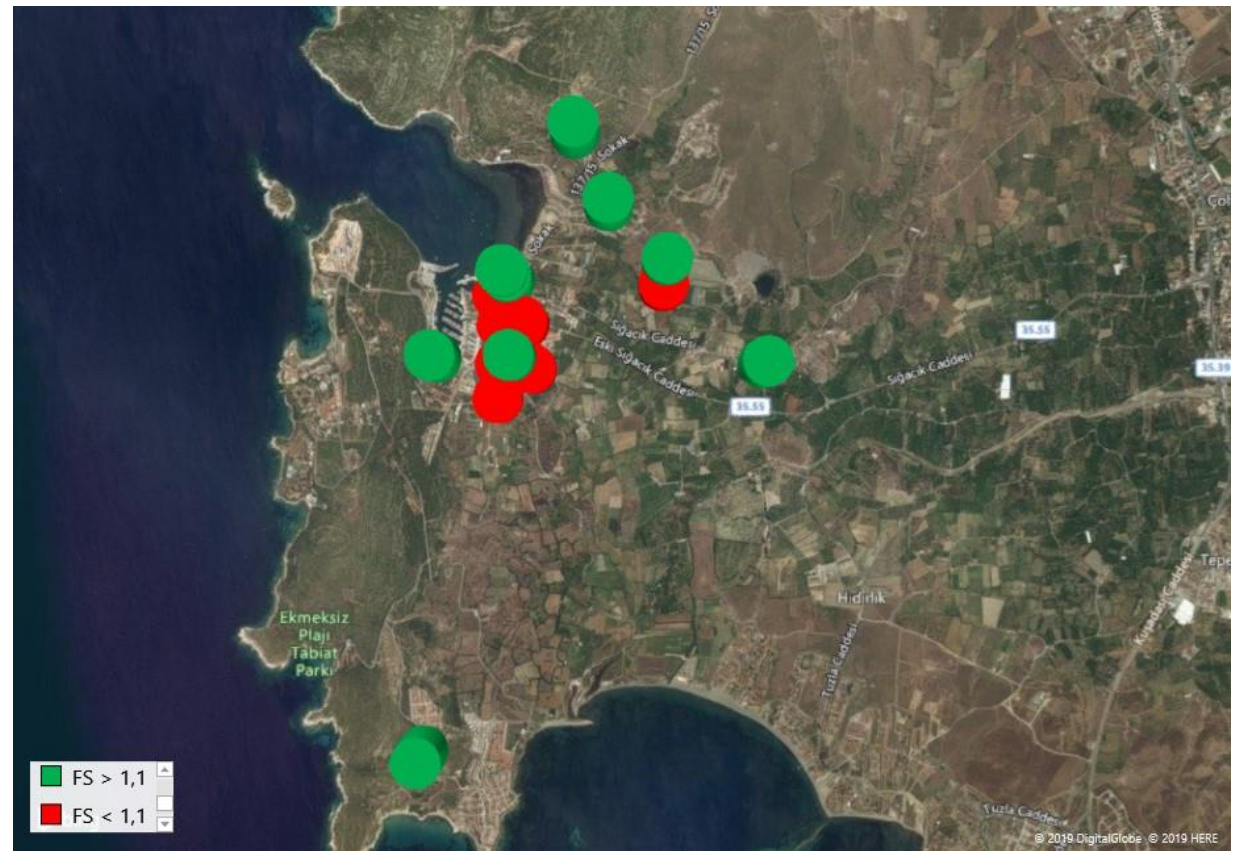

Şekil 8: Inceleme alanı verilerine ait 2. senaryoya ( $D D 3$ ve $M w=7)$ göre sıvılaşma risk haritası

Çalışma bölgesindeki 2. Senaryoya göre yapılan değerlendirmelere göre toplam 17 noktanın 8'inde sıvılaşma riski tespit edilmiş diğer 9 nokta ise sıvılaşma açısından risksiz olarak değerlendirilmiştir. Diğer bir deyişle ilgili bölgede yapılan hesapların \%47'sinde sıvılaşma riski bulunduğu tespit edilmiştir. Aynı bölgedeki 3. Senaryoya göre ise 5 noktada sıvılaşma riski tespit edilmiş olup bölge 3. Senaryoya göre \%71 oranında güvenli olarak belirlenmiştir. Deprem büyüklüğünün azalması ile sıvılaşma riskinin de azalması beklenen bir sonuçtur. Bununla beraber, çalışma alanının, yaşanabilecek olası bir 7,5 büyüklüğündeki deprem göz önüne alındığında oldukça büyük bir risk içerdiği görülmektedir.

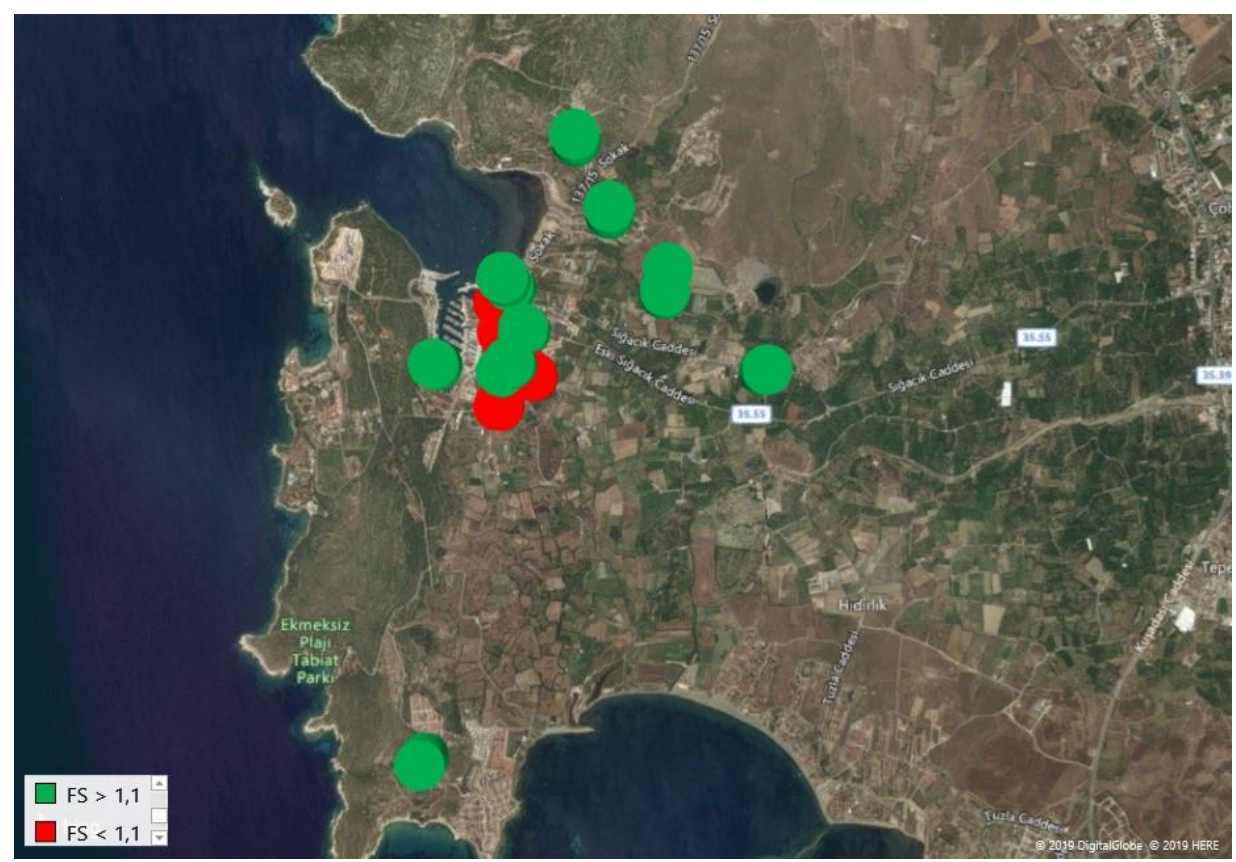

Şekil 9: Inceleme alanı verilerine ait 3. senaryoya (DD4 ve $M w=6,5)$ göre sıvılaşma risk haritası

$\mathrm{Bu}$ çalışmadaki kohezyonsuz zeminlerin olası oturma hesapları yukarıdaki analizlerden 1. Senaryoya ait olan güvenlik katsayıları kullanılarak gerçekleştirilmiştir. Bu durum, en olumsuz koşulu kapsamaktadır. Oturma hesaplarının derinlik boyunca gerçekleştirilmesi gerekmektedir fakat mevcut raporlardaki verilerin yetersizliği sebebi ile bazı noktalarda derinlik boyunca bazılarında ise tabaka başına değerlendirme gerçekleştirilmiştir. 
Tüm veriler kullanılarak elde edilen tahmini sıvılaşma kaynaklı oturma sonuçları ise Tablo 6'da sunulmuştur. Tahmini oturma miktarları Ishihara ve Yoshimine (1992) yöntemi için her tabakada 11,8 ile 27,9 cm değerleri arasında değişmekte ve bir parsel için en çok $73,8 \mathrm{~cm}$ değerine ulaşmaktadır. Bununla beraber Çetin vd. (2009) yönteminde ise her tabakada 8,1 ile 27,2 cm değerleri arasında değişmekte ve bir parsel için en çok 63,8 cm değerine ulaşmaktadır. Çalışma alanında gerçekleşecek olası bir 7,5 büyüklüğündeki deprem için hesaplanan tahmini oturma değerleri her iki yöntemde de parsel bazında değerlendirildiğinde, $50 \mathrm{~cm}$ değerlerini aşarak oldukça büyük oturmalara sebep olacağ sonucuna varılmaktadir.

Tablo 6: Inceleme alanı kapsamında yapılan oturma hesabı

\begin{tabular}{|c|c|c|c|c|c|}
\hline $\begin{array}{c}\text { ADA - } \\
\text { PARSEL }\end{array}$ & SPT & $\begin{array}{c}\text { TABAKA } \\
\text { KALINLIĞI } \\
(\mathbf{m})\end{array}$ & FS & $\begin{array}{c}\delta_{\text {ishihara }} \\
(\mathbf{c m})\end{array}$ & $\begin{array}{c}\boldsymbol{\delta}_{\text {cetin }} \\
(\mathbf{c m})\end{array}$ \\
\hline $91-65$ & 11 & 4,25 & 0,41 & 17,9 & 11,7 \\
& 11 & 5,00 & 0,20 & 22,5 & 20,0 \\
& 11 & 5,50 & 0,17 & 26,4 & 22,0 \\
& & & & $\sum_{\delta}=66,8$ & $\sum_{\delta}=53,7$ \\
\hline $1279-1$ & 16 & 5,00 & 0,34 & 16,5 & 12,0 \\
\hline $1163-1$ & 5 & 4,00 & 0,28 & 21,2 & 13,6 \\
\hline $89-140$ & 3 & 4,00 & 0,15 & 22 & 16 \\
\hline $93-11$ & 9 & 4,00 & 0,22 & 17,8 & 13,2 \\
\hline $1123-8$ & 20 & 4,50 & 0,52 & 13,7 & 8,1 \\
\hline $1161-10$ & 21 & 8,00 & 0,58 & 22,4 & 12,4 \\
\hline $51-6$ & 14 & 4,35 & 0,29 & 15,7 & 9,8 \\
& 17 & 5,20 & 0,25 & 18,5 & 14,0 \\
& 16 & 6,80 & 0,21 & 27,9 & 27,2 \\
& 22 & 3,20 & 0,25 & 11,8 & 12,8 \\
& & & & $\sum_{\delta}=73,8$ & $\sum_{\delta}=63,8$ \\
\hline
\end{tabular}

\section{Sonuçlar}

Deprem etkisi sonucunda zeminlerde meydana gelen ve oldukça tehlikeli ve istenmeyen bir durum olan sıvılaşma olgusu bu çalışmada, yeni yönetmeliğe uygun şekilde tanıtılıp örneklendirilmiş ve Sığacık bölgesinden elde edilen arazi deneyleri sonuna göre incelenmiş ve değerlendirilmiştir. $\mathrm{Bu}$ çalışmada kullanılan etüt verileri Seferihisar Belediyesi'nden elde edilmiştir. Çalışma kapsamında, yeraltı su seviyesinin yüksek olduğu ve SPT deneyi sonuçlarına göre zemin profilinin gevşek olduğu anlaşılmıştır. Bu durum incelenen alanlar ve yakın çevresi için risk teşkil etmektedir.

Yeni yönetmelik ile yapılan değerlendirmelerde kullanılacak olan veriler, eski yönetmeliğe göre hazırlanan mevcut raporlarda nadiren tam olarak bulunmuştur. Zemin etüt raporlarının en kritik verilerinden olan birim hacim ağırlık, SPT gibi değerlerin mevcut raporlarda olmadığı ve/veya eksik halde sunulmuş olduğu anlaşılmıştır. Tüm raporların incelenmesi ile analizlerde kullanılmak üzere 18 adet rapor seçilmiştir. Bu raporların bir kısmında birim hacim ağırlık değerleri yok iken SPT değerlerinin mevcut olduğu görülmüştür. Bahsi geçen bu noktalarda yakın çevredeki benzer zeminler gözetilerek zemin özelliklerine uygun olacak şekilde kabuller yapılarak analize devam edilmiştir. Bununla beraber, birbirine çok yakın inceleme noktalarının yeraltı suyu seviyelerinde de oldukça büyük farklılıklar olduğu tespit edilmiştir. Şekil 6'da sıvılaşma riski bulunmayan tüm noktalarda (yeşil renk ile gösterilen) bu durum, sadece yeraltı suyunun ilgili etüd raporlarında "yeraltı su seviyesi bulunmamaktadır" ibaresinden yola çıkarak belirlenmiştir. Belirtilen bu noktalara çok yakın olan diğer noktalarda ise yeraltı su seviyeleri en çok $3 \mathrm{~m}$. derinlikte tespit edilmiştir. Bu durum ilgili raporların güvenilirliğini sorgulatmaktadır.

Sonuç olarak, farklı deprem senaryolarına göre analizler gerçekleştirilmiş ve inceleme sahası içinde 1. Senaryo için hesap yapılan noktaların \%65'i sıvılaşma için riskli olarak nitelendirilmiştir. 2. Senaryoda sıvılaşma riski azalmış ve $\% 47$ ye kadar inmiştir. 3. Senaryoda ise, 5 noktada sıvılaşma riski bulunmuş olup ilgili bölge \%71 oranında güvenli olarak belirlenmiştir. Çalışma alanında gerçekleşebilecek 7,5 büyüklüğündeki bir deprem (1. Senaryo) için oldukça büyük bir sıvılaşma riski olduğu tespit edilmiştir. Bununla beraber, 1. Senaryo için aynı zamanda tahmini oturma miktarları da iki yöntem kullanılarak hesaplanmış ve parsel bazında olası oturmaların her iki yöntemde de $50 \mathrm{~cm}$ 'yi aştı̆̆ 1 sonucuna ulaşılmıştır. Verilerin tüm derinlik boyunca oturma tahmini yapmaya yetmediği noktalarda ise tabaka başına hesap yapılmış ve 8,1-27,9 cm arasında değişen oturma miktarları hesaplanmıştır. 


\section{Teşekkür}

Çalışma süresince mevcut zemin etüt raporlarını paylaşan Seferihisar Belediyesi’ne teşekkür ederiz.

\section{Kaynaklar}

Akbuğa E., (2019), Seferihisar (İzmir) bölgesinde sıvılaşma analizi ve haritalandırılması, Yüksek Lisans Tezi, Manisa Celal Bayar Üniversitesi, Manisa, Türkiye.

Bray J.D., Macedo J., (2017), 6th Ishihara lecture: Simplified procedure for estimating liquefaction-induced building settlement, Soil Dynamics and Earthquake Engineering, 102, 215-231.

Cetin K.O., Seed R.B., Der Kiureghian A., Tokimatsu K., Harder L.F., Kayen R.E., Moss R.E.S., (2004), Standard penetration testbased probabilistic and deterministic assessment of seismic soil liquefaction potential, J. Geotech. Geoenviron. Eng., 130(12), 1314-1340.

Çetin K.O., Bilge H.T., Wu J., Kammerer A.M., Seed R.B., (2009), Probabilistic model for the assessment of cyclically-induced reconsolidation (volumetric) settlements, J. Geotech. Geoenviron. Eng., 135(3), 387-398.

Çetin K.O., Bilge H.T., (2010), Zeminlerin sismik yükleme altında deformasyon ve mukavemet davranışlarına kritik bakıs, Zemin Mekaniği ve Temel Mühendisliği 13. Ulusal Kongresi, 30 Eylül - 1 Ekim, İstanbul Kültür Üniversitesi, İstanbul, Türkiye.

Drahor M.G., Sarı C., Şalk M., (1999), Seferihisar jeotermal alanında doğal gerilim (SP) ve gravite çalışmalarl, 9 Eylül Üniversitesi Mühendislik Fakültesi, Fen ve Mühendisliği Dergisi, 1(3), 97-112.

Emre Ö., Özalp S., Doğan A., Özaksoy V., Yıldırım C., Göktaş F., (2005), İzmir yakın çevresinin diri fayları ve deprem potansiyelleri, MTA rapor no:10754, Maden Tetkik ve Arama Genel Müdürlüğü, Jeoloji Etütleri Dairesi, Ankara, 80ss.

Erdoğan B., (1990), İzmir-Ankara Zonu ile Karaburun kuşağının tektonik ilişkisi, M.T.A. Dergisi, 110, 1-15.

Huang Y., Yu M., (2013), Review of soil liquefaction characteristics during major earthquakes of the twenty-first century, Natural Hazards, 65, 2375-2384.

Hyde A.F.L., Higuchi T., Yasuhara K., (2006), Liquefaction, cyclic mobility, and failure of silt, J. Geotech. Geoenviron. Eng., 132(6), 716-735.

Ishihara K, Yoshmine M., (1992), Evaluation of settlements in sand deposits following liquefaction during earthquakes, Soils and Foundations, 32(1), 173-188.

Isobe K., Ohtsuka S., Nunokawa H., (2014), Field investigation and model tests on differential settlement of houses due to liquefaction in the Niigata-ken Chuetsu-Oki earthquake of 2007, Soils and Foundations, 54(4), 675-686.

ISSMGE/TC4, (1999), Manual for zonation on seismic geotechnical hazards, Tech. Com. For Earthquake Geotechnical Engineering TC4, ISSMGE, Japanese Society of Soil Mechanics.

İnci U., Sözbilir H., Sümer Ö., Erkül F., (2003), Urla-Balıkesir arası depremlerin nedeni fosil bir fay, Cumhuriyet Bilim ve Teknik Dergisi, 21, 7-8.

Karakan E., Tanrinian N., Sezer A., (2019), Cyclic undrained behavior and post liquefaction settlement of a nonplastic silt, Soil Dynamics and Earthquake Engineering, 120, 214-227.

Mele L., Flora A., (2019), On the prediction of liquefaction resistance of unsaturated sands, Soil Dynamics and Earthquake Engineering, 125, 105689, doi: 10.1016/j.soildyn.2019.05.028.

Mele L., Tan Tian J., Lirer S., Flora A., Koseki J., (2019), Liquefaction resistance of unsaturated sands: experimental evidence and theoretical interpretation, Geotechnique, 69(6), 541-553.

MTA, (2018), Türkiye jeoloji haritasl/geological map of Turkey, http://www.mta.gov.tr/v3.0/sayfalar/hizmetler/doc/IZMIR.pdf, [Erişim 20 Şubat 2018].

Ocakoğlu N., Demirbağ E., Kuşçu İ., (2004), Neotectonic structures in the area offshore of Alaçatı, Doğanbey and Kuşadası (western Turkey): evidence of strike-slip faulting in the Aegean extensional province, Tectonophysics, 391(1-4), 67-83.

Ocakoğlu N., Demirbağ E., Kuş̧̧u İ., (2005), Neotectonic structures in İzmir Gulf and surrounding regions (western Turkey): Evidences of strike-slip faulting with compression in the Aegean extensional regime, Marine Geology, 219(2-3), 155-171.

Takch E.A., Sadrekarimi A., Naggar E.H., (2016), Cyclic resistance and liquefaction behavior of silt and sandy silt soils, Soil Dynamics and Earthquake Engineering, 83, 98-109.

TBDY, (2018), Türkiye bina deprem yönetmeliği, Resmi Gazete, Tarih: 18 Mart 2018, Say1: 30364, https://www.resmigazete.gov.tr/ eskiler/2018/03/20180318M1-2.htm, [Erişim 20 Şubat 2018].

Thevanayagam S., Martin G.R., Shenthan T., Liang J., (2001), Post-liquefaction pore pressure dissipation and densification in silty soils, Fourth International Conference on Recent Advances in Geotechnical Earthquake Engineering and Soil Dynamics, 26-31 March, Missouri University of Science and Technology, Rolla, Missouri, USA.

UDIM, (2005), 17-21 Ekim 2005 Siğacık Körfezi-Seferihisar (İZMiR) depremleri ön değerlendirme raporu, Boğaziçi Üniversitesi, Kandilli Rasathanesi ve Deprem Araştırma Enstitüsü, Ulusal Deprem İzleme Merkezi, 6 ss.

Y1lmazer S., (1979), İzmir Seferihisar (URLA L17-C1) yöresinin jeolojisi, MTA rapor no:6834, Maden Tetkik ve Arama Genel Müdürlüğü, Jeoloji Etütleri Dairesi, Ankara.

Youd T.L., Idriss I.M., Andrus R.D., Arango I., Castro G., ......, Stokoe K.H., (2001), Liquefaction resistance of soils: Summary report from the 1996 NCEER and 1998 NCEER/NSF workshops on evaluation of liquefaction resistance of soils, Journal of Geotechnical and Geoenvironmental Engineering, 127(10), 817-833.

Yoshimi Y., Tanaka K., Tokimatsu K., (1989), Liquefaction resistance of a partially saturated sand, Soils and Foundations, 29(3), 157-162. 